\title{
Inmate Empowerment Through Training in Making Bags Made of Rope as a Provision of Skills
}

\author{
Triana Kumala Dewi ${ }^{1 *}$, Rosi Ayu Sholihah ${ }^{2}$, Aries Luvieta Sarie ${ }^{3}$, R. Bekti Kiswardinata ${ }^{4}$, \\ Pinkan Amita Tri Prasasti ${ }^{5}$
}

1,2,3,4,5 Fakutas Pendidikan dan Ilmu Pendidikan, Universitas PGRI Madiun

\section{A R T I C L E I N F O}

Article history:

Received 15 May 2018

Received in revised form

10 Juny 2018

Accepted 20 July 2018

Available online 25 August 2018

Keywords:

Inmates, Training, Skills,

Crease bag strap

\begin{abstract}
A B S T R A CT
Community service team, Elementary School Teacher Education Universitas PGRI Madiun has conducted training in making bags made from raw rope for inmates in prison Ngawi class II B as a provision of skills. The purpose of the abdimas is (1) Provision of skills to the prisoner by inviting the prisoners to perform a creation in the form of a rope bag (2) to create economic independence for the prisoners through training on making bags made from rope, (3) to encourage or support the prisoner again have confidence. Training activities begin with the opening and delivery of materials and discussion and evaluation. Training in making bag made from rope made with direct practice in bag making. Training training is emphasized on improving skills and motivational motivation for prisoners to remain confident in their work. It can be concluded that in the training of making bags made from raw rope has been done with bai. Based on the questionnaire results, $86 \%$ of participants gave an assessment that the training of bag making made from raw ropes for prisoners in Ngawi Class II class B institution is very motivating in increasing the skills of the participants.
\end{abstract}

\footnotetext{
${ }^{*}$ Corresponding author.

E-mail addresses: pinkan.amita@unipma.ac.id (Pinkan Amita Tri Prasasti)
} 


\section{Introduction}

Prisoners are convicts who undergo crimes of lost independence in the correctional institution. Although convicts lost their independence, there were prisoners' rights that remained protected in the Indonesian prison system. Whereas the conviction of the convicted person is someone who is convicted based on a court decision that has obtained permanent legal force. Skills are very important for everyone including prisoners, without the skills we have, we cannot create innovative creativity.

The underlying thing in the making of this program was because most of the prisoners and prisoners were in Corectional Institution Ngawi Yos Sudarso Margomulyo street, Ngawi Regency, East Java who did not have basic skills after leaving Corectional Institution. The number of prisoners and prisoners is too much in Corectional Institution For a total of 186 adult inmates, consisting of 182 adult male inmates, 4 female adult inmates and 6 male inmates. So that a total of 192 adult inmates and child prisoners. Whereas the total number of prisoners in Corectional Institution Ngawi was located desperately needs a special skill to be able to increase income in the LAPAS and to compete in the community after leaving Corectional Institution. So after exiting LAPAS, former inmates can make or establish a business or get entrepreneurship from the handicrafts in the form of string bags for increase the family's economy and go directly to the community. Prisoners need to be provided with training and training to create a skill in the form of knitting bags so that inmates after being free from Corectional Institution have creativity that will benefit the community and benefit themselves. Prisoners need to be equipped with knit bag crafts because the making is easy, the material is relatively cheaper and the results are very interesting for the community. The manufacture of this bag requires materials in the form of a rope, croton and requires tools such as scissors and matches. In the creation of bags made of rope, most of the people are not yet known by many people, because in the process of making and a small part of the community can not make a rope bag creation. that. So that it can provide entrepreneurial opportunities for prisoners after leaving prison and the inmate can open a business from the results of the debriefing of creativity that has been given by students in the form of a rope bag to their community.

The main force for the implementation of this program is aimed at all cadres or organizations in the community and also for students whose quality is crucial in an effort to improve the quality of the skills implemented. Thus, the ability of prisoners in Corectional Institution Ngawi must be developed to the full potential. With the provision of knowledge and skills adapted to the task carried out in order to play an active role in improving prisoner skills in Corectional Institution Ngawi. Therefore, it is expected that the Student Creativity Program can help inmates through counseling and training to improve prisoners' own knowledge and skills, so as to produce prisoners who think creatively and innovatively.

\section{Method}

The training on making creations of bags made from rope for inmates in Ngawi Prison class II B as a skill provision was carried out in Corectional Institution, having the address at Yos Sudarso Margomulyo street, Kec. Ngawi, Kab. Ngawi, East Java 63217. Training for 2 months is April to May. The development method that will be implemented is a series of steps that are arranged systematically, here is an overview of the flow map that will run.

The following is a chart of the implementation of the training in making bags made from rope. 


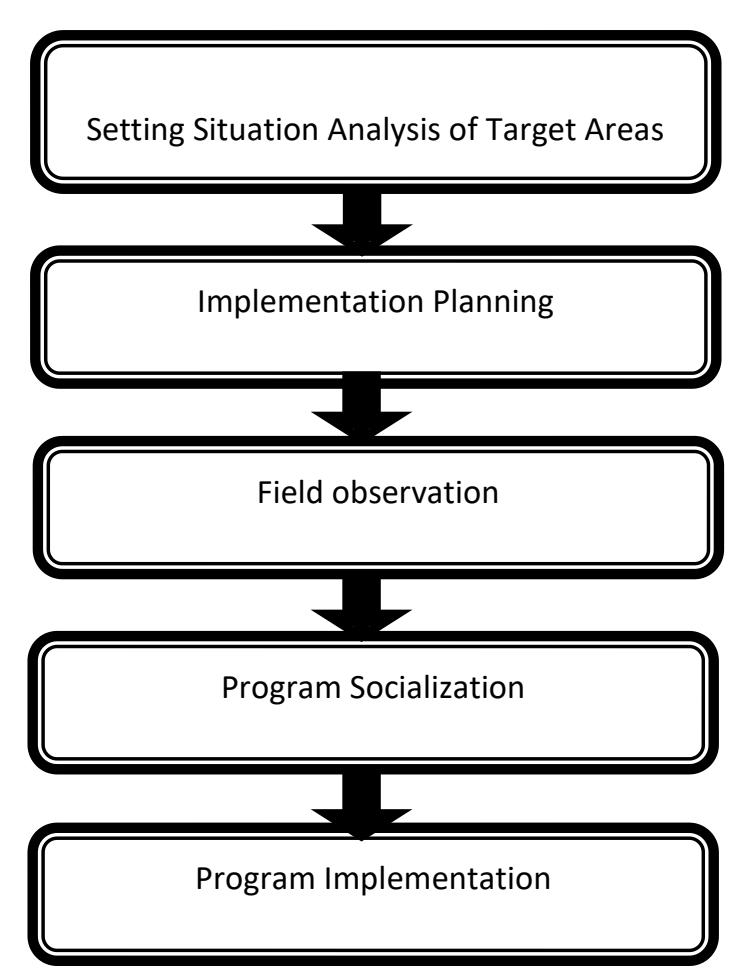

Figure1. Chart of Bag Creation Training Implementation

In addition to the flow map above, there is also a chart for bag creation training during the Corectional Institution Ngawi. There are several stages of training in making bags made from string, following the training plan for making bags made from rope.

The evaluation system carried out on prisoners' performance while carrying out training in making bag-based bag creations is to provide and add skills to prisoners and improve the skills that inmates have had before. The indicator of the success of the service program is that inmates who take training receive skills from those who do not have the skills and who also have their own skills. So that inmates get skills in the form of making bags of rope made of raw materials that they have never received. 


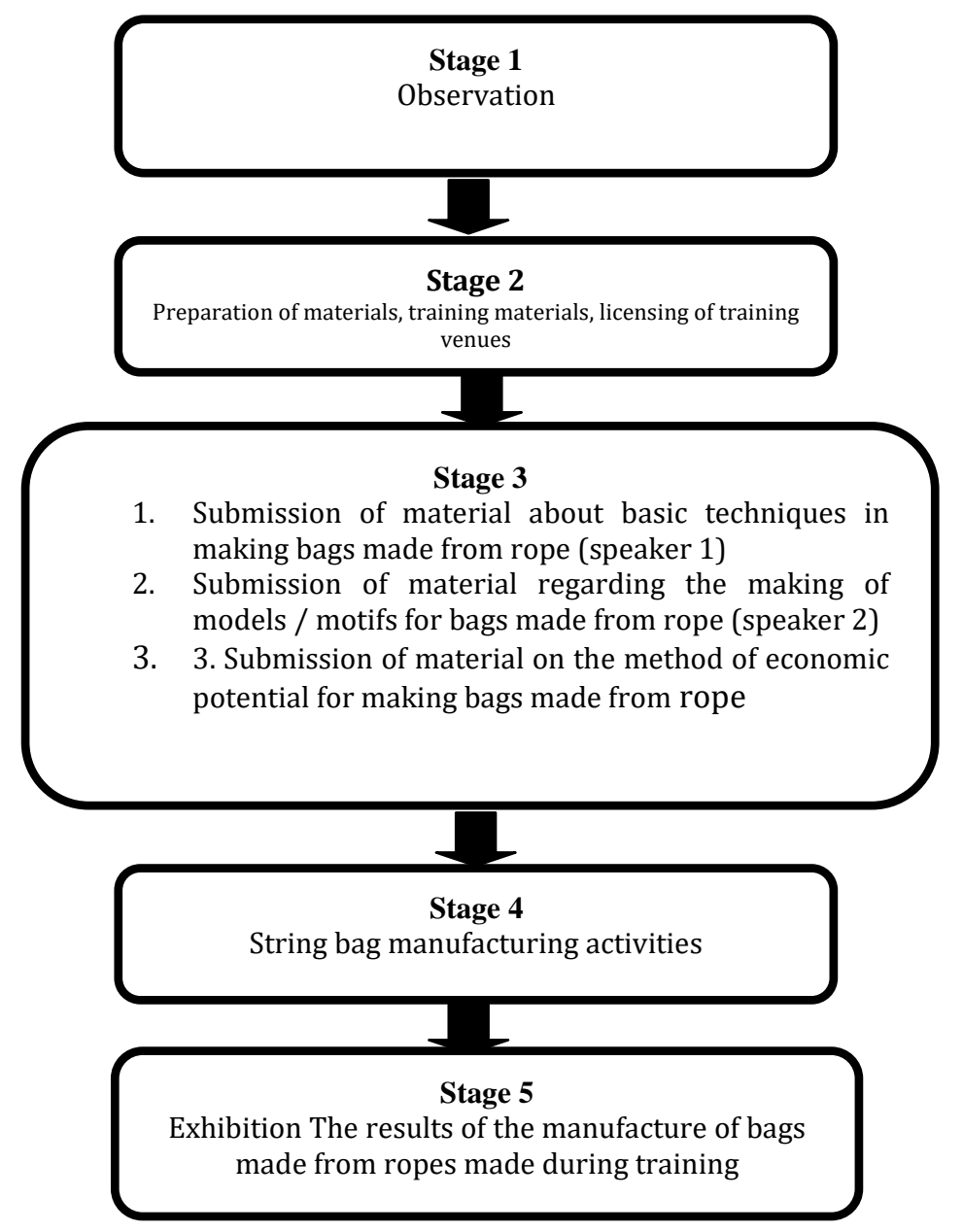

Figure 2. Chart of Bag Creation Training Implementation

\section{Result dan Discussion}

Community Service with the theme of training in the manufacture of bags made from rope to inmates in Corectional Institution as skills. In the implementation of training bags made from ropes made up to stage 6, namely stage 1 observation activities in Corectional Institution Ngawi, stage 2 material preparation activities, stage 4 material delivery, stage 3 training implementation, stage 5 finishing.

Stage 1

The implementation of community service activities starts from observation to Corectional Institution on April 7, 2018. Observation activities are carried out to find out the destination of the training. Observations were made by interviewing the Corectional Institution head. Observation activities were continued on April 14, 2018 with activities to determine the schedule of activities to be carried out during Corectional Institution Ngawi and to determine the theme of community service. In addition to determining the theme of the community service team and the Corectional Institution also determines the time and place of the activity.

Stage 2

Phase 2, namely preparation activities include preparing training materials; that is; material about basic techniques in making bags made from ropes. The material is packaged in powerpoint so that the bag is practically easy to understand by participants. Other preparations are coordination with the Corectional Institution to request permission to carry out training activities and to prepare a place, prepare materials and tools to be used in making bags.

Stage 3

The third stage of community service activities on April 19, 2018 was in the implementation of training activities in the manufacture of bags made from ropes. In the implementation of training, bag making was preceded by the opening of the head of Corectional Institution then continued with a speech by the supervisor and continued by the community service team leader. After the opening of the Head of 
Corectional Institution and remarks from the supervisor and the head of the community service team, continued with the delivery of material regarding the manufacture of bags made of rope. Participants who attended this training were 7 female prisoners in Corectional Institution Ngawi.
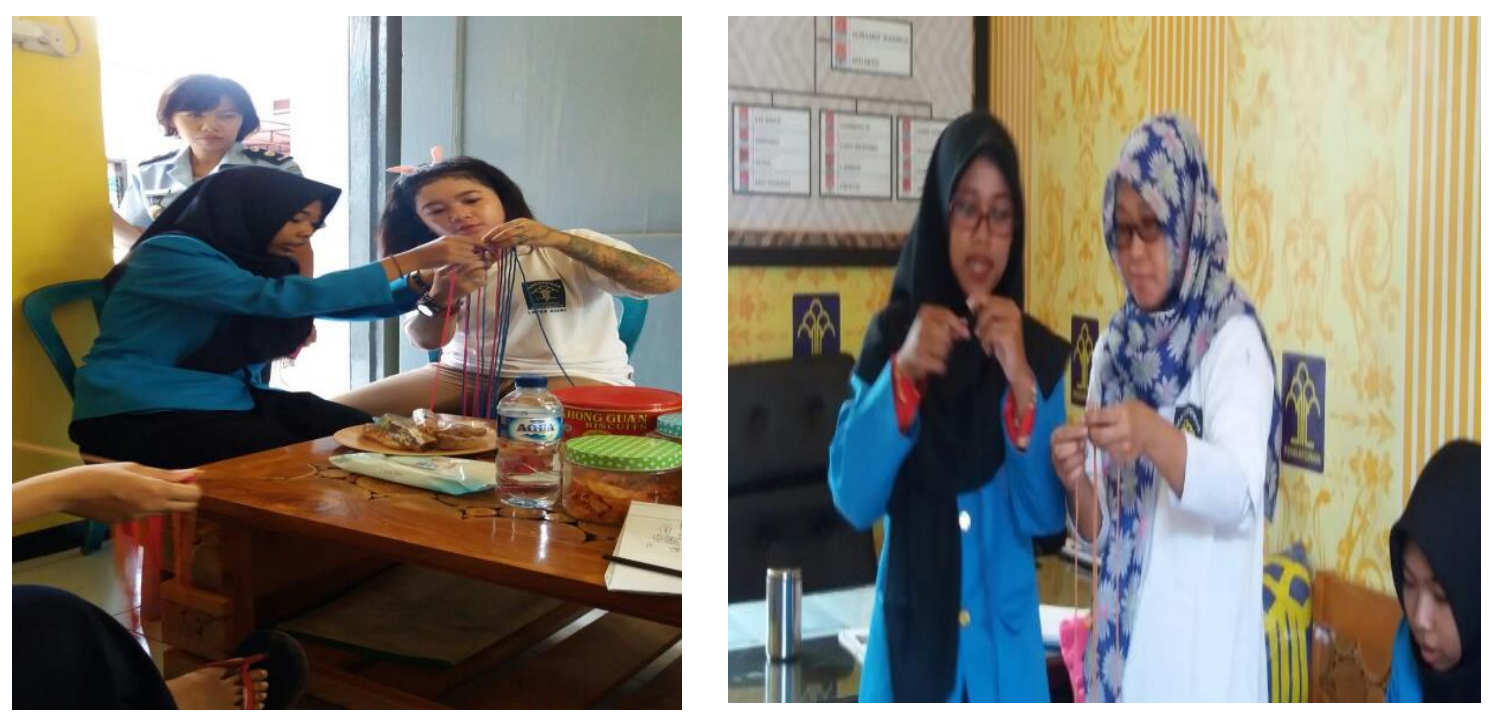

Figure 3. Submission of Material by Team

Submission of the first material was delivered by members of the community service team, An Nisa Subroto, with basic technical material in making bags in the form of bag heads and how to arrange several heads into a series. Submission of the first material was carried out for 15 minutes by explaining directly to participants

After the submission of the material one was completed, followed by the delivery of the second material which will be delivered by the community service team leader by Triana Kumala Dewi about making motifs / bag models. Submission of material two was carried out for 20 minutes with direct delivery and also direct practice by participants.

The material points presented regarding the motives to be made by the participants. From the technique of making different motifs and bag models.Subsequently, after the presentation of the material two was finished, continued with the delivery of the third material by a member of the community service team, namely Aries Luvieta Sarie regarding the making of the bag base. In the delivery of material three, it was carried out for 15 minutes by delivering it directly to participants by way of practice.

After the delivery of the material was completed, continued with a question and answer activity regarding bag making. Many participants asked about bag making because participants were still confused in making the technique until the end of bag making. Participants show the results made to the speaker, and the speaker explains again and confirms the results of the participants if there is a wrong manufacturing technique.

Stage 4

After the third phase was completed, then the fourth stage was the training on making creations of bags made of ropes for female prisoners in Corectional Institution Ngawi. In the implementation of training on making bags made from cord made on 23 April 2018, the activities carried out were in the form of training. creation of bag creation by inmates at Corectional Institution Ngawi. Participants conduct training in the creation of bags made from rope, from making the head of the bag to the end of making bags in the form of bags. Participants make heads according to the amount that has been determined and after finishing make the head continue by arranging the head into a series. Next, go to the steps for the process of making different bag motives between participants. The final step in making a bag is to make the bag base and enter the croton into the bag. Here the participants are given time to complete the manufacture of bags made from rope until May 5, 2018.

Stage 5

The fifth stage was held on May 5, 2018, namely the finishing process and the product marketing process in the form of bags into small exhibitions / bazaars. The Pesert who has made a bag made of rope according to the techniques that have been delivered is directed to try to make other motives. As well as participants who have not finished in making the bag directed and also assisted in the finishing process of 
the bag. There are only 4-5 people who have finished making bags, and others are still in the process of completion. After everything is finished in the bag making process, the products produced are marketed at the small exhibition / bazaar that is on the Corectional Institution it self. Skills training as one of the coaching programs is categorized into other inmates while undergoing skills and also as a provision for the scope of prisoner coaching is to make inmates can associate inmates in the process of reintegration with the community. Skills development as one of the prisoner coaching programs will be carried out optimally by establishing cooperation through third parties both with government agencies and private parties who can provide useful skills guidance in the community if later they have expired their term in detention. Prisoners must be equipped with skills in accordance with their ability so that prisoners are able to live independently and are able to compete with the community without committing more crimes. With the skills training program for prisoners it is very important that the goal of the prison is achieved. Prisoners will have mental and have good skill

\section{Conclusion}

The training on making creations of bags made of ropes for prisoners in Corectional Institution can be concluded that in the training of making bags made from raw materials, the rope has been done well. Participants were able to complete the bag making, and there were 3 people who completed a bag of 3 bags per person. Participants here have started to pursue bag making, so that of the 7 participants, all of them are already proficient in bag making.

Suggestions for training in making bags made from rope should be more intensive at the training stage. Because at the time of the bag-making training, there were still some participants who did not understand so the participants were a little confused in making the basic parts of the bag. The community service team should be more intensive when conducting guidance to participants.

\section{Refrence}

Ardilla, F., \& Herdiana, I. (2013). Penerimaan diri pada narapidana wanita. Jurnal psikologi kepribadian dan sosial, 2(1), 1-7Harida, H. N. (2010). Kegiatan Pelatihan Keterampilan Bagi Narapidana (Studi Kasus Pada Lembaga Pemasyarakatan Anak Klass IIA Blitar). SKRIPSI Jurusan Pendidikan Luar Sekolah-Fakultas Ilmu Pendidikan UM.

Hukum, D. K. F., Hukum, D. I., \& Camar, H. Y. Pembinaan Narapidana Dalam Pemenuhan Upah Atau Premi Di Dalam Lembaga Pemasyarakatan Kelas I Kedungpane Semarang.

Kabbaro, H., Awawin, M., Wibowo, B. A., Rahmawati, Y., \& Rachmawati, M. (2013). "Komunitas Berani Bangkit" model pembinaan tahanan dan narapidana di bawah umur di lembaga pemasyarakatan kelas iia kota bogor dengan pengembangan kewirausahaan, pengekspresian rasa melalui kreativitas seni, pengembangan kemampuan spiritual, dan pencitraan positif di kalangan masyarakat.

Lestari, D. A. (2016). Keterampilan Membatik Bagi Narapidana di Lembaga Pemasyarakatan Klas IIB Blitar. Jurnal Tata Busana, 5(1).

Mariana, A. A. (2017). Dampak Pelatihan Life Skill Terhadap Perkembangan Kreativitas Narapidana Di Cabang Rumah Tahanan Kotapinang (Doctoral Dissertation, Unimed).

Mayasari, R., Mansur, M., Mursalat, M., \& Fajrin, F. (2016). Pengembangan Resiliensi Narapidana Perempuan Muslim melalui Pelatihan Keterampilan Resiliensi Islam.

Mudiarti, L. (2017). Pemberdayaan Mantan Narapidana Di Kabupaten Jepara Melalui Pelatihan Pengolahan Aneka Produk Perikanan. Jurnal Disprotek, 7(2).

Perdana, R. P. (2014). Pengaruh Program Pelatihan Terhadap Kompetensi Narapidana Pada Lembaga Pemasyarakatan Kebonwaru Kota Bandung (Doctoral dissertation, Universitas Widyatama).

Pradiantiwi, D., Safitri, R. W., \& Prasasti, P. T. A. (2018). Character Education For Prisoners Soft Skills To Empower Through Asinan Trasi In The Correctional Instution Ngawi. Research Report.

Team, R. (2012). Gambaran Orientasi Masa Depan Narapidana Remaja Sebelum dan Setelah Pelatihan di Rumah Tahanan Negara Kelas 1 Bandung. Majalah Keperawatan Unpad, 12(1).

Yulianti, S. A., \& Widiasih, R. (2009). Gambaran orientasi masa depan narapidana remaja sebelum dan setelah pelatihan di rumah tahanan negara kelas 1 bandung. Jurnal Psikologi, 10, 97-104. 